\title{
SLSCによる水文頻度解析モデル適合度評価 への統計的仮説検定の導入

\author{
INTRODUCING A STATISTICAL HYPOTHESIS TESTING INTO SLSC \\ GOODNESS-OF-FIT EVALUATION FOR HYDROLOGICAL FREQUENCY \\ ANALYSIS MODELS
}

\author{
林敬大 ${ }^{1} \cdot$ 立川康人 ${ }^{2} \cdot$ 椎葉充晴 ${ }^{3} \cdot$ 萬 $^{\text {和明 }}{ }^{4} \cdot \mathrm{Kim} \mathrm{Sunmin}^{5}$ \\ Hiromasa HAYASHI, Yasuto TACHIKAWA, Michiharu SHIIBA, Kazuaki YOROZU, \\ and Sunmin KIM \\ 1 学生会員 学（工） 京都大学修士課程 大学院工学研究科（ 615-8540 京都市西京区京都大学桂 C1） \\ 2 正会員 博（工） 京都大学准教授大学院工学研究科（７ 615-8540 京都市西京区京都大学桂 C1） \\ 3 正会員 工博京都大学教授 大学院工学研究科（† 615-8540 京都市西京区京都大学桂 C1） \\ 4 正会員 博 (工) 京都大学助教大学院工学研究科（T 615-8540 京都市西京区京都大学桂 C1） \\ 5 正会員 博 (工) 京都大学講師 大学院工学研究科（） 615-8540 京都市西京区京都大学桂 C1）
}

\begin{abstract}
A goodness-of-fit evaluation for hydrologic frequency models using SLSC (Standard Least Squares Criterion) is widely used in Japan. As the critical value to the SLSC goodness-of-fit evaluation, 0.03 is usually used. However, the critical value is recognized as a variable depending on a sample size of hydrologic data and a hydrologic frequency model. In this study, statistical characteristics of SLSC is examined. Then, based on the analysis, a statistical hypothesis testing is introduced into the SLSC goodness-of-fit evaluation for hydrological frequency analysis models.
\end{abstract}

Key Words: hydrological frequency analysis, statistical hypothesis testing, null hypothesis, composite hypothesis, goodness-of-fit, SLSC, monte carlo simulation

\section{1.はじめに}

河川計画を策定する際，観測された極值水文データ をある確率分布に従う母集団の実現值であるとした上 で，候補に挙げられる水文頻度解析モデル群から最も 良いモデルを選択し，確率水文量を推定して想定外力 を定める手法が一般的に用いられている. その際, 水 文頻度解析モデルを選択するための何らかの評価規準 が必要となる。

我が国では，宝・高棹 ${ }^{1)}$ によって提案された SLSC (Standard Least Squares Criterion, 標準最小二乗規 準) を用いる手法が広く利用されている。この手法で は，SLSC の值がある基準值を上回る水文頻度解析モ デルを候補から除外し, 次に候補に残ったモデルから 得られる確率水文量の安定性を Jackknife 法あるいは Bootstrap 法によるリサンプリング手法によって評価し て, 確率水文量の推定值のばらつきが最も小さいモデ ルを選択する。

このとき，水文頻度解析モデルの選択規準に用いる SLSC の基準值をどう定めるかは, 注意を要すると考え る. 葛葉 ${ }^{2}$ は, データのサンプル数が大きくなるにつ れて SLSC の值はより小さな值をとりやすくなること をモンテカルロシミュレーションによって示し, SLSC
によって適合度を評価する際にはサンプル数を考慮に 入れる必要があることを指摘した. SLSCによって適合 度を評価する際，基準值として 0.03 ではなく 0.04 とい う值が用いられることもあるようである。これは，田 中・宝 ${ }^{3)}$ が河川流量の極值データに多数の水文頻度解 析モデルを当てはめた結果, SLSC が 0.03 以下となる 場合が少なく, 0.04 という值で適合度の十分性を評価 すべきであると指摘したためであると考えられる.

田中・宝 ${ }^{3)}$ はSLSC が 0.03 以下となる場合が少ない 原因として，河川水位から水位流量曲線を用いて換算 した河川流量のデータ特性にその理由を求めているが, そのときのデータサンプル数に着目すると興味深い考 察ができる．宝・高棹 1 ) で扱われた水文データのサン プル数は，大阪の年最大日降水量が 92 個，大津・彦根 の年最大 $k$ 日降水量 $(k=1,2,3)$ がそれぞれ 74 個, 琵 琶湖流域平均の年最大 $k$ 日降水量 $(k=1,2,3)$ が 70 個 であり，平均して標本数は75 個程度である。これに対 して田中・宝 ${ }^{3)}$ で扱われた水文データのサンプル数は, 標本数が $40 \sim 44$ 個のデータが 40 地点, 35 ～ 39 個 あるいは 45〜 49 個あるものがそれぞれ 18 地点, 平均 して標本数は 42 個程度である。このサンプル数の違い のために田中・宝 ${ }^{3)}$ が扱った流量データではSLSC の 值が宝・高棹 ${ }^{1)}$ と比べて大きくなり，基準值を 0.03 か 
ら 0.04 にする必要があった可能性がある.

SLSC による適合度評価が十分にされるためには，サ ンプル数を考慮に入れた新しい適合度評価が必要にな ると考える. そこで本論では，サンプル数による SLSC の統計的特性を分析したうえで，サンプル数を考慮に 入れた統計的仮説検定の考え方を SLSCによる水文頻 度解析モデルの適合度評価に導入することを試みる。

\section{2. 統計量として見たSLSC の分布特性}

\section{(1) SLSC の概要}

SLSC は，確率紙においてプロットされたサンプル データの直線性を定量的に評価するための指標であり, 異なるモデルに対しても適合度を同じ指標で統一的に 評価できるように配慮されている. SLSC の值 $S_{c}$ は次 式で与えられる.

$$
\begin{gathered}
S_{c}=\frac{\sqrt{\xi_{\text {min }}^{2}}}{\left|s_{q}-s_{1-q}\right|} \\
\xi_{\text {min }}^{2}=\frac{1}{N} \sum_{i=1}^{N}\left(s_{(i)}-s_{(i)}^{*}\right)^{2}
\end{gathered}
$$

ここに， $s_{(i)}$ はサンプルデータ $x_{i}(i=1, \ldots, N)$ を小さい 順に並べ替えた順序統計量 $x_{(i)}$ を

$$
s_{(i)}=\frac{x_{(i)}-\hat{\mu}}{\hat{\sigma}}
$$

によって標準化した標準変量， $\hat{\mu} ， \hat{\sigma}$ はそれぞれサンプ ルデータに対して推定される位置母数, 尺度母数, $s_{q}$, $s_{1-q}$ はそれぞれ非超過確率 $q, 1-q$ に対する標準変量 である. 一般的に $q=0.99$ として用いられているため, 本研究でもそれに倣うことにする.

また, $s_{(i)}^{*}$ は位置母数を 0 , 尺度母数を 1 とした場合 の水文頻度解析モデルに従うサンプルデータを小さい 順に並べかえた標準変量の期待值である. $s_{(i)}^{*}$ は，水文 頻度解析モデルに対応するプロッティングポジション 公式

$$
P_{i}=\frac{i-\alpha}{N+\beta}
$$

を用いて，

$$
s_{(i)}^{*}=F^{-1}\left(P_{i}\right)
$$

によって求められる.ここで，F(.) は位置母数を 0 , 尺 度母数を 1 とした場合のモデルの確率分布関数である.

\section{(2) 母数の与え方による SLSC の分布の違い}

正規分布を例として SLSC の確率密度関数をモンテ カルロシミュレーションによって経験的に得ることを考 える. 葛葉 ${ }^{2)}$ はモデルの母数を, データを発生させる 正規分布の母数と同じものとした場合の SLSC の分布 を求めたが, それに加えてモデルの母数をサンプルデー タから推定する場合のSLSC の分布も求める. 議論を明
確にするために，モデルの確率分布関数を $F(x \mid \boldsymbol{\theta})$ で表 し, サンプルデータに対して推定された母数を $\hat{\boldsymbol{\theta}}$ で表 すことにする. また, 母集団の従う確率分布を「真の分 布」とよび, その確率分布関数を $G(x \mid \Theta)$ で表すことに する. 真の分布がもつ母数は固定されていると想定し, その母数を $\Theta^{*}$ で表す. 以下，a) では $F(x \mid \boldsymbol{\theta}) \equiv G(x \mid \boldsymbol{\Theta})$ かつ $\boldsymbol{\theta}=\boldsymbol{\Theta}^{*}$ であるときの SLSC の確率分布を，b) で は $F(x \mid \boldsymbol{\theta}) \equiv G(x \mid \boldsymbol{\Theta})$ であるときのSLSC の確率分布を, 正規分布の場合について求める.

\section{a) モデルの母数を固定母数とする場合}

$F(x \mid \boldsymbol{\theta}) \equiv G(x \mid \boldsymbol{\Theta})$ かつ $\boldsymbol{\theta}=\boldsymbol{\Theta}^{*}$ とした場合，想定する モデルの分布は真の分布と全く同じものとなるが, サ ンプルデータによって，モデルの適合度を表すSLSC の 值は異なる. すなわちSLSC は確率変数であり, 統計 量として扱う必要があることがわかる.

そこで，SLSC の分布特性を論じるために，葛葉 2)を 参考にしてSLSC の確率密度関数を経験的に求めるこ とを考える. 具体的には以下の手順を踏む.

1. 標準正規分布 $\mathrm{N}(0,1)$ から $N$ 個のサンプルデータ $x^{j}=\left(x_{1}^{j}, x_{2}^{j}, \ldots, x_{N}^{j}\right)$ を発生させる. $j$ は繰り返し回 数を意味する添え字である.

2. 手順 1 で発生させたデータの確率分布モデルとし て，真の分布と同じ正規分布で，なおかつ真の分布 と同じ母数をもつ標準正規分布モデルを想定する.

3. 手順 1 のデータに対する標準正規分布モデルの適 合度を表すSLSC の值 $S_{c, j}$ を求める.

4. 手順 $1 \sim 3$ の試行を 10000 回繰り返し, $S_{c, j}(j=$ $1,2, \ldots, 10000)$ を得る.

5. 10000 個の $S_{c, j}$ の相対度数ヒストグラムを作成し, 近似的にSLSC の確率密度関数を得る.

これは，真の分布と同じ母数を固定母数として与えた モデルをサンプルデータに対して想定したときのSLSC の確率密度関数であるが, 実は一般に, 真の分布のもつ 母数を $\mu=0, \sigma=1$ ではなく $\mu=\mu^{*}, \sigma=\sigma^{*}(-\infty<$ $\left.\mu^{*}<\infty, \quad 0<\sigma^{*}<\infty\right)$ としてもSLSC の分布は同じも のになる. なぜなら, SLSCの值を求める際には, サン プルデータは標準化されるため, 結局真の分布のもつ 母数を変えてもSLSC の分布は変わらないためである.

図-1 は上記の手順によってもとめた SLSC の確率密 度関数である.プロッティングポジション公式として Cunnane 式（(4) 式で $\alpha=0.4 ， \beta=0.2 ）$ を採用した. 図-1 を見ると, SLSC の確率密度関数はデータのサン プル数が増えるに従って, 期待值, 分散がともに小さ くなり, 分布は左にシフトする. この結果をふまえて, 葛葉 ${ }^{2)}$ はサンプル数に応じて異なる SLSC の基準值を 用いるべきであることを指摘し，SLSC を確率分布する 統計量として捉え, 設定したSLSC の基準值の分位值 を示した.

\section{b) モデルの母数を自由母数とする場合}

a) では，想定する正規分布モデルの母数は $\mathrm{N}\left(\mu=\mu^{*}\right.$, 


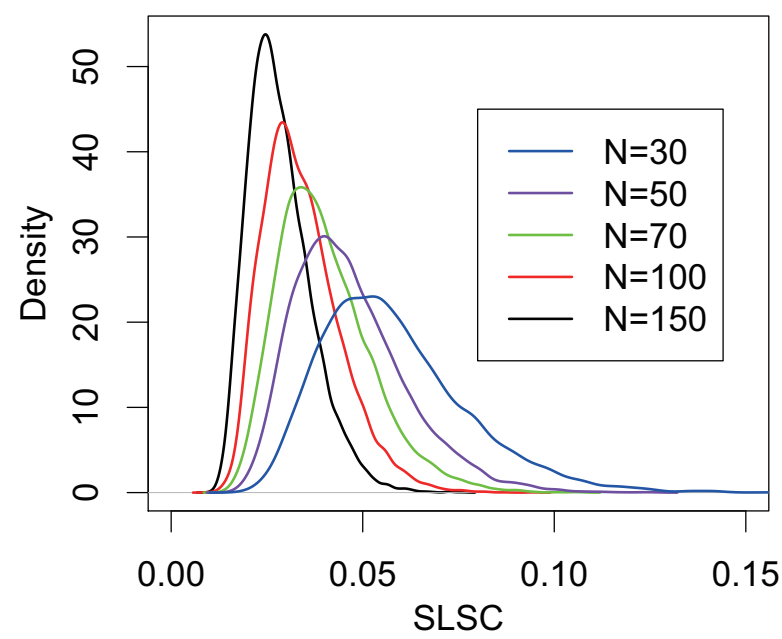

図-1 シミュレーションによって得た正規分布の場合のSLSC の確率密度関数. $N$ はデータのサンプル数であり, $N$ が 大きくなるにつれて，分布は左にシフトする.

$\left.\sigma=\sigma^{*}\right)$ としてあらかじめ固定した結果を示した.し かし実際に水文データを確率分布モデルに当てはめる 場合は，母数は未知であり，サンプルデータに対して 積率法や PWM 法, 最尤法などの何らかの母数推定法 によって母数を推定することが一般的である. そこで, ここでは確率分布モデルの母数を a) のように固定する のではなく，推定するものとして考える．この場合の SLSC の確率分布も, a) の手順と同様にして求めるこ とができる．ただし，モデルの母数は発生させたサン プルデータに対してその都度推定し，その求めた母数 を持つ確率分布モデルに対して SLSC を求める.

このときのSLSC の確率分布は, 図-1 で求めたもの とは異なる。一般に, サンプルデータに対して推定さ れた母数をもつモデルは，母集団の従う真の分布より もサンプルデータに対して適合度が良い。図-2(a) にお いて，真の分布と同じ母数をもつモデル（黒い破線の グラフ）のSLSC の值は 0.036 であるのに対し，推定 された母数をもつモデル（青い実線のグラフ）の SLSC の值は 0.014 である. そのため, 図-2(b) が示すように, 母数を推定する場合の SLSC の確率密度関数は期待值, 分散がともに小さくなり, 左にシフトする.

\section{(3) モデルが異なる場合の SLSC の分布の違いについて} a) 正規分布の場合と Gumbel 分布の場合の比較

水文頻度解析によく用いられるモデルには正規分布, 対数正規分布, Gumbel 分布, GEV 分布, ピアソン 3 型分布, 対数ピアソン 3 型分布なら゙, 形状の異なる様々 な分布がある．現行のSLSC による適合度評価手法で は，観測されたデータに対していずれのモデルを想定 する場合にも，ある定められた SLSC の基準值（0.03 や0.04）より小さいか否かで適合度を評価する. SLSC の值が基準值を超える場合には，想定されたモデルは 「適合度が不十分である」として候補モデル群から外さ れる.もし当てはめる確率分布モデルによって SLSC の 分布が異なるならば，同じ SLSC の基準值を用いると

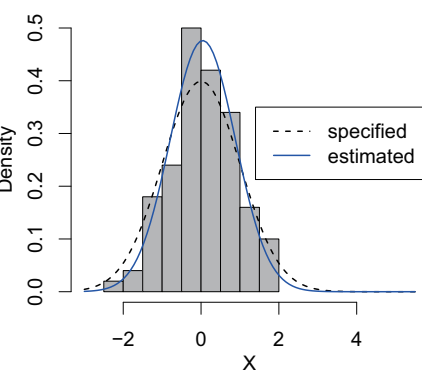

(a) サンプルデータとモデル.

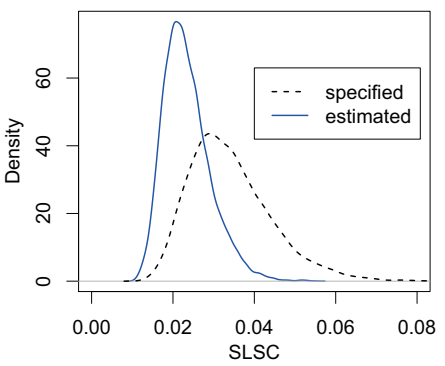

(b) SLSC の確率密度関数.

図-2 真の分布と同じ母数を固定母数として与えた場合（specified) と, モデルの母数を最尤推定した場合 (estimated) のSLSC の比較. 真の分布を標準正規分布としサンプル 数を 100 個とした場合.

基準值の超過確率も異なる.

そのため，想定するモデルによって SLSC の分布が 変わるか否かについても, データのサンプル数の問題 と同様に注意深く考える必要がある. SLSC の分子だけ を適合度の評価指標とすると, 確率分布モデルによっ て (標準) 順序統計量 $S_{(i)}$ のばらつきの様子が大きく異 なるため, 想定するモデルによって適合度の評価指標 の分布が変わることになる. SLSC はこの点を考慮し て, モデルの分布の広がりを表す $\left|s_{q}-s_{1-q}\right|$ で分子を除 算することによって, ある程度モデルの違いを排除し ている.しかしながら, 実際にはこの操作だけでは, モ デル間の評価指標の分布の統一化が十分になされない. この事実を示すために，2(2)b) と同様の手順によって, Gumbel 分布の場合の SLSC の確率分布を求め, 正規 分布の場合と比較する.

図-3(a) はサンプル数 100 のときの, 正規分布の場合 と Gumbel 分布の場合の SLSC の確率密度関数である. 図を見ればわかるように, Gumbel 分布のほうが下に 潰れた格好になっている. SLSC 值 0.04 の超過確率は, 正規分布の場合 0.013 , Gumbel 分布の場合 0.14 であ り，正しいモデルを誤って候補から外してしまう確率 は, Gumbel 分布のほうが正規分布に比べて 10 倍程度 大きく, Gumbel 分布の場合のほうが適合度の評価と して厳しい. このことからわかるように, 異なる確率 分布モデルに対して, SLSCによる適合度評価は公平な 判断を下しているとはいえない.

\section{b) 順序統計量の分散の点からの考察}

図-3(b) は，縦軸にSLSC の (1) 式，(2) 式における順 序統計量 $s_{(i)} /\left|s_{0.99}-s_{0.01}\right|$ の標準偏差を, 横軸にその順 序を表している. 図が示すように, 裾が長いところで $s_{(i)} /\left|s_{0.99}-s_{0.01}\right|$ の值が大きくなっていることがわかる. Gumbel 分布のような右裾の長い分布では, 特にその 部分で $s_{(i)}$ のばらつきが大きくなり, $\left|s_{0.99}-s_{0.01}\right|$ で除算 してもなおモデルの形状の違いによる影響を打ち消す ことができていない. 結果として SLSC の值も正規分 布の場合に比べて大きくばらつくことになり，図-3(a) のようにSLSCの確率密度関数の右裾が厚くなる. 


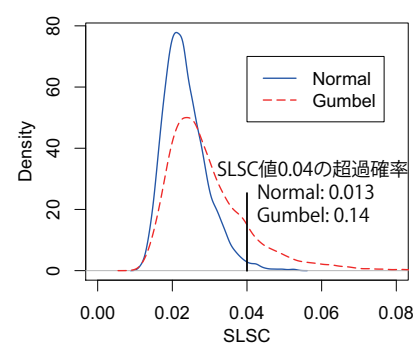

(a) SLSC の確率密度関数.

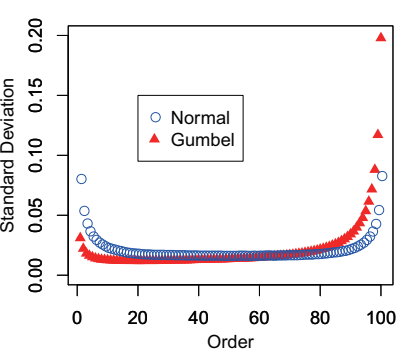

(b) $s_{(i)} /\left|s_{0.99}-s_{0.01}\right|$ の標準

偏差.
図-3 モデルの母数を最尤推定した場合の正規分布と Gumbel 分布の比較. サンプル数は 100 とした.

\section{SLSC を検定統計量とした適合度の統計的仮説 検定の導入}

既に述べたように，現行の手法のようにある定めら れた基準值で適合度を評価する場合に，SLSC の確率分 布が異なれば，その基準值の超過確率，すなわち適合 度の評価としての厳しさが異なることになる. そこで, SLSC の基準值を固定するのではなく，葛葉 2) が指摘 するように, 超過確率をある基準で固定し, その超過 確率に対応する SLSC の值を適合度評価の基準值とし て利用し，異なるサンプル数やモデルに対しても適合 度を統一的に評価することを考える. SLSC の確率分布 は2.の手順で得ることができるので, 以降では SLSC を検定統計量とした適合度の統計的仮説検定の導入を 試みる。

\section{(1) 適合度の統計的仮説検定の概要 \\ a) 有意水準と第一種の過誤}

サンプルデータに対してある仮説が正しいと主張で きる場合にも，そのサンプルデータの母集団に対して 同じ仮説が正しいと主張できるとは限らない.サンプ ルデータがその仮説にとって偶然都合の良いものであっ た可能性が否定できないためである。そこで，母集団 に関してもその仮説が妥当であることを統計的に検証 する必要性が生じる. そのための有力な手法が統計的 仮説検定である.

以下では, SLSCによる適合度評価への統計的仮説検 定の導入を試みる. 寸なわち, SLSC を検定統計量とし て捉えなおし, 有意水準 $\alpha$ に対応する SLSC の革却域 を各モデル, 各サンプル数に対して求め, 第一種の過 䛊（正しいモデルを想定しているのにそれを棄却して しまう過誤）を起こす確率を異なるサンプル数や異な る確率分布モデルに対して統一的に評価することを考 える.

\section{b) 単純仮説と複合仮説}

SLSC の萧却域について具体的に議論する前に, ど のような帰無仮説を想定するのかについて確認する. 2(2)a) では，モデルの母数は真の分布の母数と同じも
のを与えていた。この場合の帰無仮説 $\mathrm{H}_{0}$ は，「真の分 布は $\mathrm{N}\left(\mu^{*}, \sigma^{*}\right)$ である」であり, モデルの母数は固定母 数である.このような仮説を単純仮説という。これに 対し 2(2)b) では，モデルの母数はサンプルデータに対 して推定されたものであった．この場合の帰無仮説 $\mathrm{H}_{0}$ は「真の分布は $\mathrm{N}(\hat{\mu}, \hat{\sigma})$ である」であり, モデルの母 数空間は点ではなく広がりを持つ.このような仮説を 複合仮説という。実際に水文データを扱う場合に，真 の分布はわからないため, 以降では複合仮説について 議論を進める。この場合, 採用する母数推定法によっ て SLSC の萧却域が異なることに注意しなければなら ない.

\section{（2） 2 母数型モデルに対する SLSC の棄却限界值}

ある 2 母数型モデルを水文頻度解析に用いる場合, 実 際にどのような基準值で適合度を評価すればよいかを 統計的仮説検定の立場から明らかにする。表-1に，正 規分布モデル, Gumbel 分布モデルの場合の SLSC の 棄却限界值を示す.上の表は，母集団が正規分布に従 うときに, サンプルデータからその分布が正規分布で あると想定する場合の判断に用いるものである。サン プル数 $N$, 有意水準 $\alpha$ を設定し, それに対応する SLSC をまとめている.この表からサンプル数, 想定する確率 分布モデル, 設定する有意水準によって, SLSC の基準 值を定めればよい. 母数推定法としては積率法, PWM 法, 最尤法の3つをとりあげた. また, プロッティング ポジション公式にはいずれもCunnane 公式を用いた. 表-1に示すように, 母数推定法による違いは極めて小 さい.

対数正規分布モデルを想定する場合には，データを 対数変換すればそのデータは正規分布に従う. そのた め, 対数正規分布モデルに対する SLSC の確率分布は 正規分布モデルに対する SLSC の確率分布と変わらず, 正規分布モデルについてのみ考えれば事足りる.

\section{(3) 3 母数型モデルの場合}

水文頻度解析においてよく扱われる 3 母数型モデル としては, 3 母数対数正規分布, GEV 分布, ピアソン 3 型分布, 対数ピアソン 3 型分布が挙げられる. これ らのモデルに対して，2 母数の場合と同様にして SLSC を検定統計量とした適合度評価に統計的仮説検定を導 入することは容易ではない.

3 母数対数正規分布は, 通常扱われる 2 母数の対数正 規分布に新たなシフト母数 $c$ を加え, $x$ 軸に関して平行 移動できるようになっている. $c \neq 0$ である場合には, サンプルデータを対数化しても正規分布には従わない. サンプルデータからそれぞれ $c$ を減算した $x_{i}-c$ を対数 化すれば正規分布に従うが，それは母数 $c$ の真值 $c^{*}$ を 知り得た場合である. 推定された母数 $\hat{c}$ はわかったと しても，その值は真值 $c^{*}$ ではないため, $x_{i}-\hat{c}$ を対数 化しても正規分布に従うという保証はない.

GEV 分布, ピアソン 3 型分布, 対数ピアソン 3 型分 
表-1 正規分布モデル（上），Gumbel 分布モデル（下）における SLSC の基準值（棄却限界值）。

\begin{tabular}{|c|c|c|c|c|c|c|c|c|c|c|c|c|c|c|c|}
\hline & \multicolumn{15}{|c|}{ Normal distribution (using Cunnane e } \\
\hline Sample & \multirow{2}{*}{\multicolumn{5}{|c|}{$\begin{array}{l}\text { Moment Method } \\
\text { ignificance Level } \alpha\end{array}$}} & \multicolumn{5}{|c|}{ PWM Method } & \multicolumn{5}{|c|}{ MLE Method } \\
\hline Size & & & & & & & Signif & ance $L$ & $\alpha$ & & & Signifi & ance L & vel $\alpha$ & \\
\hline $\mathrm{N}$ & 0.30 & 0.20 & 0.10 & 0.05 & 0.01 & 0.30 & 0.20 & 0.10 & 0.05 & 0.01 & 0.30 & 0.20 & 0.10 & 0.05 & 0.0 \\
\hline 10 & 0.058 & 0.064 & 0.073 & 0.082 & 0.098 & 0.057 & 0.063 & 0.074 & 0.085 & 0.106 & 0.063 & 0.068 & 0.078 & 0.086 & 0.103 \\
\hline 20 & 0.047 & 0.051 & 0.058 & 0.065 & & 047 & & 0.059 & & & & & & & \\
\hline 30 & 0. & 0.045 & 0.051 & 0.056 & & 1 & 0.0 & & 0. & & & & & & \\
\hline A & & 0.040 & 0.045 & 0.049 & .0 & 7 & 0.040 & 0.046 & 0.050 & & & & & & \\
\hline 50 & 0.0 & 0.037 & 0.041 & 0.045 & & & 0.037 & 0.042 & 0.046 & & & 0.037 & & & 55 \\
\hline 6 & & & 0.0 & 0.0 & & & & & & & & & & & \\
\hline & & 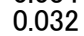 & & 0.0 & & 0.0 & 0.0 & 0.0 & 0.0 & & & & & & \\
\hline 80 & 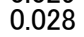 & 0 & 0.034 & 0.0 & & & & & & & & & & & \\
\hline 90 & 0.0 & & 0.0 & & & & & & & & & & & & \\
\hline 100 & & & & 0.0 & & & 0.0 & 0.0 & & & & & & & \\
\hline & 0 & 6 & 0. & & & & 00 & & & & & & & & \\
\hline & 0.0 & 0.025 & 0.029 & 0.0 & & & 0.0 & 0.0 & & & & & & & \\
\hline 124 & 0.0 & 0.0 & 0.028 & 0.0 & & 0.0 & 0.0 & & & & & & & & \\
\hline 1 & & 4 & 0.0 & 0.0 & & & & & & & & & & & \\
\hline 15 & & 0 & 0.026 & 0.0 & & & & & & & & & & & \\
\hline & & 2 & 0.025 & 0.0 & & & & & & & & & & & \\
\hline & & 0.02 & 0.0 & 0.0 & & & & & 0.025 & & & 0.021 & 0.023 & 0.025 & \\
\hline
\end{tabular}

\begin{tabular}{|c|c|c|c|c|c|c|c|c|c|c|c|c|c|c|c|}
\hline \multirow{4}{*}{$\begin{array}{c}\text { Sample } \\
\text { Size } \\
N\end{array}$} & \multicolumn{15}{|c|}{ umbel distribution (using Cunnane equation) } \\
\hline & \multirow{2}{*}{\multicolumn{5}{|c|}{$\begin{array}{l}\text { Moment Method } \\
\text { Significance Level } \alpha\end{array}$}} & \multicolumn{5}{|c|}{ PWM Method } & \multicolumn{5}{|c|}{ MLE Method } \\
\hline & & & & & & & Signif & ance $L$ & $\alpha$ & & & Signifi & ance $L$ & vel $\alpha$ & \\
\hline & 0.30 & 0.20 & 0.10 & 0.05 & 0.01 & 0.30 & 0.20 & 0.10 & 0.05 & 0.01 & 0.30 & 0.20 & 0.10 & 0.05 & 0.01 \\
\hline 10 & 0.060 & 0.066 & 0.075 & 0.084 & 0.100 & 0.057 & 0.064 & 0.074 & 0.086 & 0.113 & 0.068 & 0.078 & 0.096 & 0.119 & 0.176 \\
\hline 20 & 0.050 & 0.055 & 0.063 & 0.070 & 0.087 & 0.049 & 0.054 & 0.064 & 0.075 & & & 0.064 & 0.079 & 0.097 & 0.140 \\
\hline 30 & 0.044 & 0.049 & 0.056 & 0.064 & 0.083 & 0.044 & 0.049 & 0.058 & & & & 0.056 & 0.069 & 0.084 & \\
\hline 40 & 0.040 & 44 & 0.0 & 0.0 & 0 & 0 & 0.0 & 0.053 & & & & & & & \\
\hline 50 & 0.0 & 0.041 & 0.048 & 0.054 & .073 & 0.037 & 0.042 & 0.049 & 0. & & & 0.047 & & 0. & \\
\hline 60 & 0.0 & & 0.0 & 0. & & & 0.039 & 0.047 & 0. & & & 0.0 & & & \\
\hline 0 & & & & & & & & & & & & & & & \\
\hline 80 & 0. & 5 & 0.0 & 0.0 & 4 & & 0.0 & 0.042 & & & & 0. & & & \\
\hline 90 & & & & & & & & & & & & & & & \\
\hline 100 & & & & & & & & & & & & & & & \\
\hline & & & & & & & & & & & & & & & \\
\hline i & & & & & & & & & & & & & & & \\
\hline 13 & 0.0 & 0 & & 0.0 & & & & 0.0 & & & & & & & \\
\hline r & & & & & & & & & & & & & & & \\
\hline d & 0. & 0 & 0. & 0. & & & & & & & & & & & \\
\hline 17 & 0.025 & 0.027 & 0.0 & 0.0 & & & & & & & & & & 0.043 & \\
\hline & 04 & $0<1$ & & & & & & & & & & & & 0.041 & \\
\hline
\end{tabular}

布に関しても同じことがいえる。これらの分布は位置

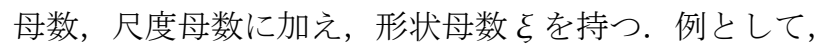
GEV 分布について考える. Gumbel 分布と一致する. 引の值が大きいほど, 分布 の右裙は厚くなる．図-4 は, GEV 分布の場合の SLSC の確率密度関数である.ただし，形状母数は $\xi=0,0.1$ , 0.2, 0.3 のつの場合を用意している. モデルの形状 母数は真の分布と同じものを与えており，他の位置母 数, 尺度母数はサンプルデータに対して最尤推定して いる. データのサンプル数は 100 とした. やはり, 形

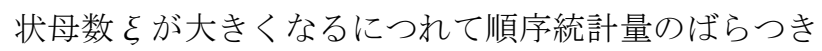
が右裾の部分で大きくなり, その結果 SLSC がばらつ くことがわかる. 形状母数の真值 $\xi^{*}$ は一般に未知であ り, 推定された母数 $\hat{\xi} か ゙ \xi^{*}$ と一致する保証はないため, 形状母数を自由母数としたモデルに対してSLSC を検 定統計量とした適合度の統計的仮説検定を導入するこ とは困難となる。

3 母数対数正規分布モデルの $c$ や GEV 分布モデルの 乡に固定母数を与えたモデルを考え, その他の母数を 推定すれば, なお SLSC を検定統計量とした適合度の 統計的仮説検定を導入することは可能となる. これも 1 つの方策として考えられる. ただし, 本来母数空間に 制約を加えなければよりよいモデルとなる可能性があ るにもかかわらず，その可能性を捨てることになる.

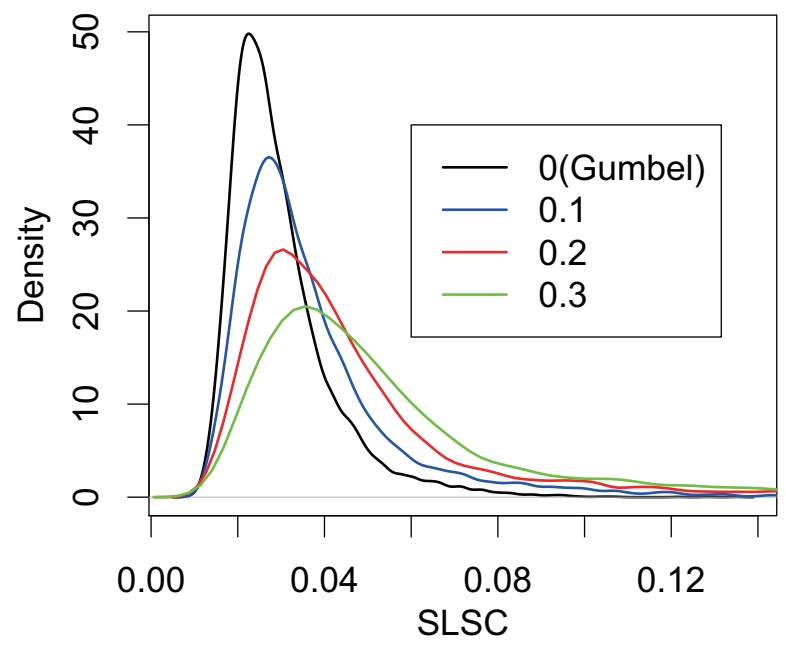

図-4 GEV 分布の場合の SLSC の確率密度関数. 形状母数 $\xi=0,0.1,0.2,0.3$ を固定し, 位置母数, 尺度母数は最 尤推定した. サンプル数は 100 とした.

\section{4. 適合度の統計的仮説検定における諸問題}

これまでに，SLSCによる適合度評価への統計的仮説 検定の導入を試みた. しかしながら，3 母数型モデルに 対しては全ての母数を推定して適合度を検定すること は困難であることがわかった。ここでは, 適合度の統 計的仮説検定における諸問題について今後の展望を含 めて考察する. 


\section{（1）有意水準設定の主観性と第二種の過誤}

想定するモデルが真の分布と一致することを，サン プルデータを以て直接証明することは不可能に近い，そ こで適合度の統計的仮説検定では，候補に挙げられる モデル群をそれぞれ真の分布であると想定したとき，観 測されたサンプルデータがそのモデルから発生するこ とがめったに起こり得ないと考えられるモデルを候補 モデル群からふるい落とし, 残ったモデルを妥当なモ デルであると考える。しかし，この「めったに起こり 得ない」という確率，すなわち有意水準の設定には主 観が伴う，有意水準の值を小さくすれば，第一種の過 誤（真の分布と同じモデルを想定しているのに候補か ら外してしまう誤り）を起こす確率は低くなるが，第二 種の過誤（真の分布とは異なるモデルを想定したのに， そのモデルを候補から外すことができない誤り）を起 こす確率が大きくなってしまう. 有意水準の設定はモ デル選択においてクリティカルな問題であるにもかか わらず，その值は $0.1 ， 0.05 ， 0.01$ といった慣例的な值 が用いられることが多い。これは第二種の過誤を起こ 寸確率を推定することが一般に困難であることによる.

\section{（2）水文頻度解析モデルの利用目的との不整合性}

確率分布モデルの適合度の統計的仮説検定では,「モ デルが真の分布であるか」を問題としている。これを モデル選択に導入することは，真の分布が最も良いモ デルであることを暗黙のうちに了解している。しかし， 水文頻度解析における「良いモデル」とは，その利用 目的を考えれば，「確率水文量に対する推定が良いモデ ル」であり，それを実現する確率分布モデルが必ずし も真の分布であるとはいい切れない.

たとえば，位置母数 0 , 尺度母数 1 , 形状母数 0.01 の GEV 分布（真の分布）からサンプルデータを発生さ せる.このデータに対し, 母数推定された Gumbel 分 布モデルと GEV 分布モデルで， $T$ 年確率水文量をそれ ぞれ推定する. モデルの母数はサンプルデータによっ て異なるため, $T$ 年確率水文量の推定值は確率変数であ

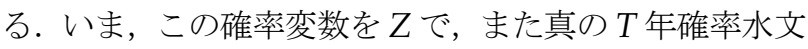
量を $z^{*}$ で表すことにすると, 平均二乗誤差 $E\left[\left(Z-z^{*}\right)^{2}\right]$ が小さいほうがモデルとして良い。これを

$$
\begin{aligned}
E\left[\left(Z-z^{*}\right)^{2}\right] & =E\left[\left\{\left(E[Z]-z^{*}\right)+(Z-E[Z])\right\}^{2}\right] \\
& =\{\operatorname{Bias}[Z]\}^{2}+\operatorname{Var}[Z]
\end{aligned}
$$

に分解して，真の分布である GEV 分布モデルとそうで ない Gumbel 分布モデルによる成績を比較したものが 表-2である。ここでは $T=100$ として超過確率 0.01 に 対応寸る確率水文量を考えた. 真の分布である GEV 分 布のほうが正確さが高く, $\{\text { Bias }[Z]\}^{2}$ が小さいが，安定 性が Gumbel 分布に比べて低いためにVar[Z] が大き くなり, 結果として真の分布ではない Gumbel 分布の ほうが平均二乗誤差が小さくなっている.

そもそも水文頻度解析において用いる確率分布はあ
表-2 100 年確率水文量に対する推定の良さ。

\begin{tabular}{cccc}
\hline モデル & $\{\operatorname{Bias}[Z]\}^{2}$ & $\operatorname{Var}[Z]$ & $E_{X}\left[\left(Z-z^{*}\right)^{2}\right]$ \\
\hline GEV & 0.0009472 & 0.6372 & 0.6382 \\
\hline Gumbel & 0.01386 & 0.1676 & 0.1815 \\
\hline
\end{tabular}

くまでモデルであり，真の分布とはなり得ないことに 注意しなければならない。数学的には, 用いる水文極 值データは独立性であること, また同一分布に従うこ とが要求されるが，実際にそうである保証はなく，ま た真の分布がある確率分布モデルで表現できる保証も ない，そのため，あくまでも真の分布をもっともらし く表現するモデルとして考えるべきであろう，水文頻 度解析に統計的仮説検定を導入する際には, モデルの 適合度を「真の分布か否か」で判断していることに注 意する必要がある。

\section{5. おわりに}

本研究では，SLSCの值が 0.03 や 0.04 といった，あ る定められた基準値を超えるか否かで適合度を判定す る現行の手法では，適合度が統一的に評価されていな いことをシミュレーションによって明らかにした。そ して，実際にごのような SLSC の基準值で適合度を評 価すればよいかを明らかにするために, 適合度の統計 的仮説検定の導入を試みた。その結果，下記の事実が 明らかとなった。

1) 検定統計量としての SLSC の確率分布はデータの サンプル数だけでなく，母数の与え方によって，ま た確率分布モデルによっても異なる.

2) 2 母数型のモデルに対しては一般的な数表を作成 することが可能であり，それを表-1に示した.

3) 3 母数型のモデルに対しては, 形状母数を固定する ならば，2 母数型のモデルと同様の取り扱いが可能 であるが，全ての母数を推定する場合には一般に 適用が困難となる。

現在は，適合度の統計的仮説検定だけでなく，情報 量規準による水文頻度解析に関する考察を進めている.

\section{参考文献}

1) 宝馨, 高棹㻟馬: 水文頻度解析における確率分布モデルの評 価規準, 土木学会論文集, No.393/II-9, pp.151-160, 1988.

2) 葛葉泰久: 治水計画策定における統計的手法一SLSC 及び 費用便益分析に関寸る考察一，土木学会論文集 B, Vol.66， No.1, pp.66-75, 2010.

3) 田中茂信, 宝馨: 河川流量の頻度解析における適合度と安 定性の評価, 水工学論文集, Vol.43, pp.127-132, 1999.

（2011.9.30 受付） 